\title{
Under-ice microbial dimethylsulfoniopropionate metabolism during the melt period in the Canadian Arctic Archipelago
}

\author{
Virginie Galindo ${ }^{1,7, *}$, Maurice Levasseur ${ }^{1}$, Michael Scarratt ${ }^{2}$, Christopher John Mundy ${ }^{3}$, \\ Michel Gosselin ${ }^{4}$, Ronald P. Kiene ${ }^{5,6}$, Margaux Gourdal ${ }^{1}$, Martine Lizotte ${ }^{1}$ \\ ${ }^{1}$ Département de biologie, Québec-Océan, Université Laval, Québec, Québec G1V 0A6, Canada \\ ${ }^{2}$ Maurice Lamontagne Institute, Fisheries and Oceans Canada, Mont-Joli, Québec G5H 3Z4, Canada \\ ${ }^{3}$ Centre for Earth Observation Science (CEOS), Faculty of Environment, Earth and Resources, University of Manitoba, \\ Winnipeg, Manitoba R3T 2N2, Canada \\ ${ }^{4}$ Institut des sciences de la mer de Rimouski (ISMER), Université du Québec à Rimouski, Rimouski, Québec G5L 3A1, Canada \\ ${ }^{5}$ Department of Marine Sciences, University of South Alabama, Mobile, Alabama 36688, USA \\ ${ }^{6}$ Dauphin Island Sea Lab, Dauphin Island, Alabama 36528, USA \\ ${ }^{7}$ Present address: Centre for Earth Observation Science (CEOS), Faculty of Environment, Earth and Resources, \\ University of Manitoba, Winnipeg, Manitoba R3T 2N2, Canada
}

\begin{abstract}
This study reports on the temporal variations in algal and bacterial metabolism of dissolved dimethylsulfoniopropionate (DMSPd) in Arctic ice-covered waters in response to the release of organic matter (OM) from the sea ice and the onset of under-ice phytoplankton growth. Sampling took place between 21 May and 21 June 2012 at a station located in Resolute Passage. A snow and ice melt event was accompanied by an important release of OM and total DMSP from the bottom ice to the water column. This input of OM coincided with increases in DMSPd and DMSPd loss rate constant at the ice-water interface and, 2 days later, with increases in DMSPd and bacterial dimethylsulfide (DMS) yields from DMSPd at $0.5 \mathrm{~m}$ under the ice. The different microbial responses suggest that DMSPd-rich brines were released first, followed by the release of sympagic algae due to ice melt. In both cases, the changes in DMSPd metabolism resulted in an increase in gross DMS production from 0.15 to $1.9 \mathrm{nmol}^{-1} \mathrm{~d}^{-1}$. The initiation of phytoplankton growth resulted in increases in bacterial abundance, DMSPd loss-rate constant and DMSP-sulfur assimilation. In contrast, DMS yield remained low during the onset of phytoplankton growth, indicating that bacteria used DMSP as a carbon and sulfur source. These results show that ice DMSPd can be rapidly $(<1 \mathrm{~d})$ and efficiently (up to $10 \%$ ) converted into DMS by bacteria once released in surface water during melt events, a process that could contribute to DMS peaks measured at the ice edge.
\end{abstract}

KEY WORDS: Arctic $\cdot$ Ice melt $\cdot$ Dimethylsulfoniopropionate $\cdot$ DMSP $\cdot$ Dimethylsulfide $\cdot$ DMS · Bacterial metabolism

Resale or republication not permitted without written consent of the publisher

\section{INTRODUCTION}

Dimethylsulfide (DMS), a degradation by-product of the algal metabolite dimethylsulfoniopropionate (DMSP; see review by Stefels et al. 2007), represents the most important natural source of volatile sulfur to the atmosphere (Kettle \& Andreae 2000, Simó 2001).
In the atmosphere, DMS can be oxidized to sulfate aerosols that scatter incoming solar radiation and form small-radius cloud condensation nuclei (CCN) that increase the albedo of low-altitude clouds. A recent global aerosol model suggests a weak response of $\mathrm{CCN}$ to changes in DMS emissions over large parts of the world ocean (Woodhouse et al. 2013). 
However, evidence of nucleation events linked to regional DMS ocean pulses shows that DMS can influence the dynamics of climate-active biogenic aerosols in remote regions such as the Arctic during spring and summer (Chang et al. 2011, Rempillo et al. 2011). During these periods, low aerosol concentrations prevail due to the atmospheric removal of numerous trace gas pollutants by oxidizing agents (Pratt et al. 2013) and precipitation (Browse et al. 2012). The impact of marine DMS emissions could be particularly important in the Arctic where warming is amplified (Pithan \& Mauritsen 2014). It has been suggested that higher DMS production and sea-to-air fluxes, as a result of greater ice-free surface areas and earlier spring blooms seeded by ice algae, could partly offset warming caused by the loss of ice albedo (Qu \& Gabric 2010).

In polar regions, the development of sea ice algae in spring results in high concentrations of DMSP and DMS. In the Arctic, maximal concentrations of particulate DMSP (DMSPp) and DMS in the bottom ice in spring range from 985 to $15082 \mathrm{nmol} \mathrm{l}^{-1}$ and from 30 to $769 \mathrm{nmol} \mathrm{l}^{-1}$, respectively (Uzuka 2003, Gilson 2010, Galindo et al. 2014). Concentrations of dissolved DMSP (DMSPd) as high as $6110 \mathrm{nmol} \mathrm{l}^{-1}$ have also been recently measured in the bottom ice of the Arctic (Galindo et al. 2014). In contrast, both DMSPp and DMSPd are generally found in low concentrations under the ice during winter and early spring (Vila-Costa et al. 2008a), except during brine release and sea-ice melt (Trevena \& Jones 2006, Tison et al. 2010, Galindo et al. 2014). The fate of these 2 sea ice DMSP reservoirs (particulate and dissolved) is expected to differ considerably once released in the water column. While DMSPp will likely sink in the water column in association with the diatoms which dominate the ice algal assemblage in the Arctic (Levasseur et al. 1994), DMSPd is expected to remain in the fresh to brackish-water lens formed under the ice by melt water. This pool of dissolved DMSP can then follow 1 of 2 pathways when consumed by bacteria: (1) a cleavage pathway leading to DMS production (i.e. DMS yield) or (2) a demethylation/demethiolation pathway promoting the formation of methanethiol and other products which can be assimilated by bacterioplankton. Demethylation of DMSPd can be accomplished by the majority of marine prokaryotes (Howard et al. 2008), and most heterotrophic bacteria found in the Arctic have the capacity to cleave DMSPd or assimilate it into biomass (Motard-Côté et al. 2012, RuizGonzález et al. 2012a). The proportion of DMSPd released from the sea ice that will be eventually cleaved into DMS by heterotrophic bacteria under the ice is unknown. In the open ocean, the DMS yield can range from 2 to $50 \%$ (e.g. Merzouk et al. 2008, Royer et al. 2010, Lizotte et al. 2012) depending on bacterial sulfur demand and availability of DMSP (Kiene et al. 2000, Pinhassi et al. 2005, Levasseur et al. 2006). The rare Arctic measurements show DMS yields varying between 12 and $31 \%$ in late summer and between 4 and $15 \%$ in autumn in the ice-free waters of the Canadian High Arctic (Luce et al. 2011, Motard-Côté et al. 2012). As heterotrophic bacteria are generally carbon-limited under the ice pack in winter and early spring (Garneau et al. 2008), the release of dissolved organic matter from the ice, including DMSP, may thus trigger a rapid bacterial response.

The objective of this study was to assess the impact of the release of organic matter and DMSP from the sea ice to the water column on algal and bacterial metabolism of DMSPd during the Arctic spring. We also document changes in algal and bacterial DMSPd metabolism associated with the onset of under-ice phytoplankton growth, which took place toward the end of our sampling period.

\section{MATERIALS AND METHODS}

\section{Study area}

This study was conducted at a landfast ice station $\left(74^{\circ} 43.613^{\prime} \mathrm{N}, 95^{\circ} 33.496^{\prime} \mathrm{W}\right)$ located between Griffith Island and Sheringham Point (Cornwallis Island) in Resolute Passage of the central Canadian Arctic Archipelago (Fig. 1). The area is typically covered by ice from November to the end of June, with maximum ice thickness of $2 \mathrm{~m}$ and heaviest snow cover in May. The water column depth at the station was $90 \mathrm{~m}$. The origins of the water masses and their circulation in the sampling area have been studied by Prinsenberg \& Bennett (1987). In this area, Arctic surface water from the Canadian Basin enters Barrow Strait from the south through Peel Sound, from the west through Viscount Melville Sound and from the north through Penny Strait. Surface waters entering from the west and south showed similar salinity as that observed in the western Archipelago (31.5 to 32.5), while surface waters from the north have higher salinity (>32.8) due to turbulent mixing with subsurface water (Prinsenberg \& Bennett 1987). Furthermore, Jones et al. (2003) showed that the Arctic surface water in Barrow Strait is entirely of Pacific origin. 


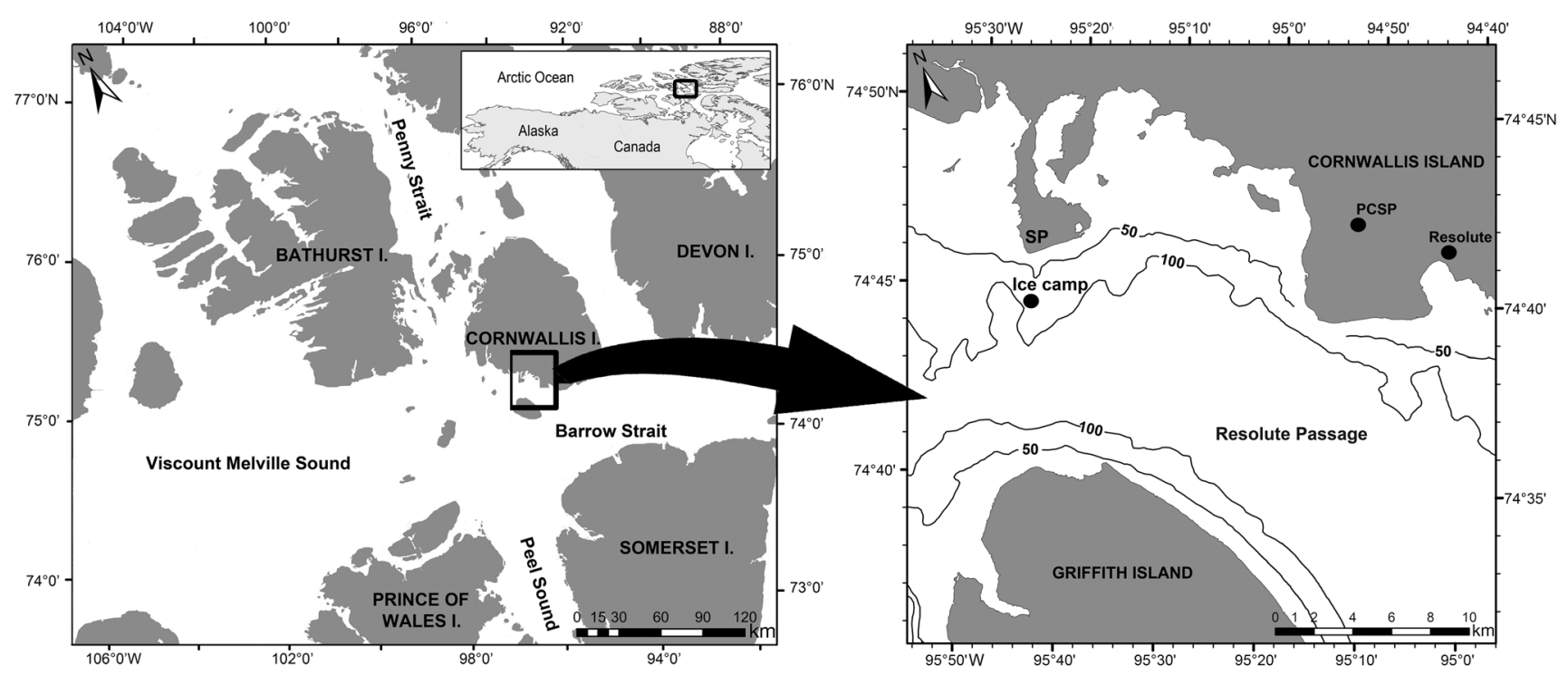

Fig. 1. Map of a section of the Canadian Arctic Archipelago (left panel) and position of the ice camp in Resolute Passage in 2012 (74 43.613' N, 95³3.496' W; right panel). The location of Sheringham Point (SP), the hamlet of Resolute and the Polar Continental Shelf Program (PCSP) Resolute Facility are also indicated. Isobaths are in meters

\section{Environmental measurements}

Physical characteristics of the sea ice and underlying surface water were measured on 15 and 30 occasions, respectively, between 21 May and 21 June 2012. On each ice-sampling day, snow depth and ice thickness were measured with a measuring stick and an ice thickness gauge (Kovacs Enterprises), respectively. Ice cores were extracted using a Kovacs Mark II coring system (diameter: $9 \mathrm{~cm}$ ). An ice temperature profile at $5 \mathrm{~cm}$ intervals was also measured on a full ice core. Immediately after ice core extraction, ice temperature was measured by drilling a $2 \mathrm{~mm}$ hole to the center of the core and inserting a temperature probe (Testo 720 probe). To determine ice salinity, a full ice core was cut in $10 \mathrm{~cm}$ sections and melted. Bulk salinity of the melted ice was measured with a hand-held conductivity meter (Cond 330i, WTW). Brine volume fraction of each $10 \mathrm{~cm}$ ice section was calculated using the recorded ice bulk salinity and temperature (Cox \& Weeks 1983, Petrich \& Eicken 2010). Ice temperatures, bulk salinity and brine volumes were then averaged over the entire ice core.

Temperature and salinity of the upper water column were measured with a Sea-Bird SBE 19plus V2 conductivity-temperature-depth (CTD) probe. Throughout the study, air temperature was monitored at 1 min intervals with a Rotronic HygroClip2 temperature probe at a meteorological station located within 0.5 to $1 \mathrm{~km}$ of our main sampling site.

\section{Sample collection}

Two ice cores were collected at a high snow-depth site $(>20 \mathrm{~cm})$ every $4 \mathrm{~d}$. The $3 \mathrm{~cm}$ bottom ice was quickly sectioned and pooled in a $7.5 \mathrm{l}$ dark isothermal container to avoid brine drainage effects. These ice core samples were melted in $0.2 \mu \mathrm{m}$ filtered seawater ( 3 parts FSW to 1 part melted ice) to minimize osmotic stress on the microbial community during melting (Bates \& Cota 1986, Garrison \& Buck 1986) and were analyzed for total DMSP (i.e. DMSPt = DMSPp + DMSPd) and DMSPd. These DMSPd concentrations were corrected for the presence of DMSPd in the filtered seawater (see calculations in 'Determination of DMSP concentrations').

Water column samples were first collected at the ice-water interface and then at $0.5 \mathrm{~m}$ under the bottom surface of sea ice through an auger hole with a battery operated plastic submersible pump (Cyclone $\left.{ }^{\circledR}\right)$ secured to the end of an under-ice arm. Seawater samples were prescreened through a $200 \mu \mathrm{m}$ Nitex mesh to remove large zooplankton grazers. Samples were processed $2 \mathrm{~h}$ after collection at the Dr. Roy M. 'Fritz' Koerner Laboratory at the Polar Continental Shelf Project facility (Fig. 1).

\section{Dissolved organic carbon and chlorophyll a}

Two samples for dissolved organic carbon (DOC) determination were filtered through pre-combusted 
$\left(450^{\circ} \mathrm{C}\right.$ for $\left.5 \mathrm{~h}\right)$ Whatman GF/F filters, and the filtrate was collected in $9 \mathrm{ml}$ glass storage vials with Teflonlined caps previously cleaned following the protocol of Burdige \& Homstead (1994). Samples were stored at $4^{\circ} \mathrm{C}$ in the dark after adding $100 \mu \mathrm{l}$ of $2 \mathrm{~N}$ hydrochloric acid $(\mathrm{HCl})$. DOC concentrations were determined on a high-temperature combustion Shimadzu TOC- $V_{\mathrm{CNP}}$ total organic carbon analyzer using the analysis procedure described by Whitehead et al. (2000). Potassium hydrogen phthalate was used to standardize DOC measurements. In addition, samples were systematically checked against low-carbon water $\left(1 \mu \mathrm{mol} \mathrm{l}{ }^{-1}\right)$ and deep seawater reference water (Florida Strait at $700 \mathrm{~m} ; 41$ to $44 \mu \mathrm{mol} \mathrm{l} \mathrm{l}^{-1}$ ) every seventh sample analysis. These seawater DOC reference standards were produced by Hansell's Consensus Reference Materials (CRM) project (www. rsmas.miami.edu/groups/biogeochem/CRM.html). The mean DOC of 3 replicate injections of each water sample showed a typical coefficient of variation $<3 \%$.

To determine chlorophyll a ( $\mathrm{chl}$ a) concentrations, two $500 \mathrm{ml}$ replicates of seawater were filtered onto Whatman GF/F $25 \mathrm{~mm}$ filters. Pigments were extracted from the filters after a minimum of $18 \mathrm{~h}$ (maximum: $24 \mathrm{~h}$ ) in $90 \%$ acetone at $4{ }^{\circ} \mathrm{C}$ in the dark (Parsons et al. 1984). Fluorescence of the extracted pigments was measured with a 10-005R Turner Designs fluorometer before and after acidification with $5 \% \mathrm{HCl}$. Chl a concentrations were calculated using the equation described by Holm-Hansen et al. (1965).

\section{Bacterioplankton abundance}

For the determination of bacterioplankton abundance, $1.8 \mathrm{ml}$ of unfiltered seawater was poured in a sterile polypropylene cryogenic vial, fixed with $25 \%$ glutaraldehyde Grade I $(0.1 \%$ final concentration, Sigma) and kept frozen at $-80^{\circ} \mathrm{C}$ until flow cytometric analysis. Frozen samples were thawed in a $30^{\circ} \mathrm{C}$ water bath and were stained with SYBR Green I (Invitrogen) following Belzile et al. (2008). Bacteria were counted with an Epics Altra flow cytometer (Beckman Coulter) fitted with a $488 \mathrm{~nm}$ laser operated at $15 \mathrm{~mW}$. The cytograms obtained were analyzed using Expo32 v1.2b Software (Beckman Coulter). Based on the side scatter vs. green fluorescence plots, bacteria were ascribed to a low nucleic acid (LNA) or high nucleic acid (HNA) category, and the criteria for distinguishing these categories was used for the whole sampling period.

\section{Determination of DMSP concentrations}

Duplicate sea ice and triplicate seawater samples were collected for the determination of DMSPt and DMSPd. DMSPp concentrations were obtained by subtracting DMSPd from DMSPt concentrations. We used the ice melt technique (Garrison \& Buck 1986), which minimizes DMSP exudation due to osmotic shock. The limitation of this sampling technique (potential underestimation of DMSPp concentrations) is detailed by Galindo et al. (2014). For DMSPt, $3.5 \mathrm{ml}$ of melted ice or seawater was gathered into a $5 \mathrm{ml} \mathrm{Falcon}{ }^{\mathrm{TM}}$ tube, while DMSPd was quantified using the small-volume gravity drip filtration (SVDF) technique (Kiene \& Slezak 2006). DMSP samples $(3.5 \mathrm{ml})$ were preserved with $50 \mu \mathrm{l}$ of $50 \%$ sulfuric acid $\left(\mathrm{H}_{2} \mathrm{SO}_{4}\right)$. Samples were analyzed using a purge and trap system coupled to a Varian 3800 gas chromatograph (GC), equipped with a Pulsed Flame Photometric Detector (PFPD). The analytical detection limit was $0.01 \mathrm{nmol}^{-1}$ for all sulfur compounds.

Sea ice DMSP concentrations were corrected for the dilution of ice core sections in FSW. Sea ice DMSPd concentrations were corrected for the presence of DMSPd in FSW using the following equation:

$$
\mathrm{C}_{\mathrm{ICE}}=\left(\mathrm{C}_{\mathrm{BULK}} \times \mathrm{V}_{\mathrm{BULK}}-\mathrm{C}_{\mathrm{FSW}} \times \mathrm{V}_{\mathrm{FSW}}\right) / \mathrm{V}_{\mathrm{ICE}}
$$

where $\mathrm{C}_{\mathrm{ICE}}, \mathrm{C}_{\mathrm{BULK}}$ and $\mathrm{C}_{\mathrm{FSW}}$ are the DMSPd concentrations $\left(\mathrm{nmol}^{-1}\right)$ of the $3 \mathrm{~cm}$ bottom ice, the melted ice with FSW and the FSW used to melt the sea ice, respectively. $\mathrm{V}_{\text {ICE }}, \mathrm{V}_{\mathrm{BULK}}$ and $\mathrm{V}_{\mathrm{FSW}}$ are the respective liquid volumes $\left(\mathrm{l}^{-1}\right)$.

\section{Determination of algal and bacterial DMSPd metabolism in surface waters}

For the determination of algal and bacterial DMSPd uptake and metabolism, triplicate samples of seawater were amended with the radiolabeled tracer ${ }^{35} \mathrm{~S}-\mathrm{DMSPd}\left(<0.01 \mathrm{nmol} \mathrm{l}^{-1}\right)$, according to the method presented in Fig. 2. Briefly, ${ }^{35} \mathrm{~S}$-amended samples in $71 \mathrm{ml}$ brown polyethylene bottles (previously washed with $\mathrm{HCl}$ and rinsed with MilliQ water) were gently mixed, and the total initial radioactivity (Tot) was determined by collecting $1 \mathrm{ml}$ with a micropipette from each bottle after $5 \mathrm{~min}$. After that, half of the bottles were used to determine the time-course of ${ }^{35} \mathrm{~S}-\mathrm{DMSPd}$ loss, while the other half was used for the DMS yield experiments. First, a ${ }^{35}$ S-DMSPd loss time-course experiment was conducted for $3 \mathrm{~h}$ in the dark at $-1{ }^{\circ} \mathrm{C}$. Subsamples were collected at time (T) $0,30,60$ and $180 \mathrm{~min}$ and filtered on syringe filters 

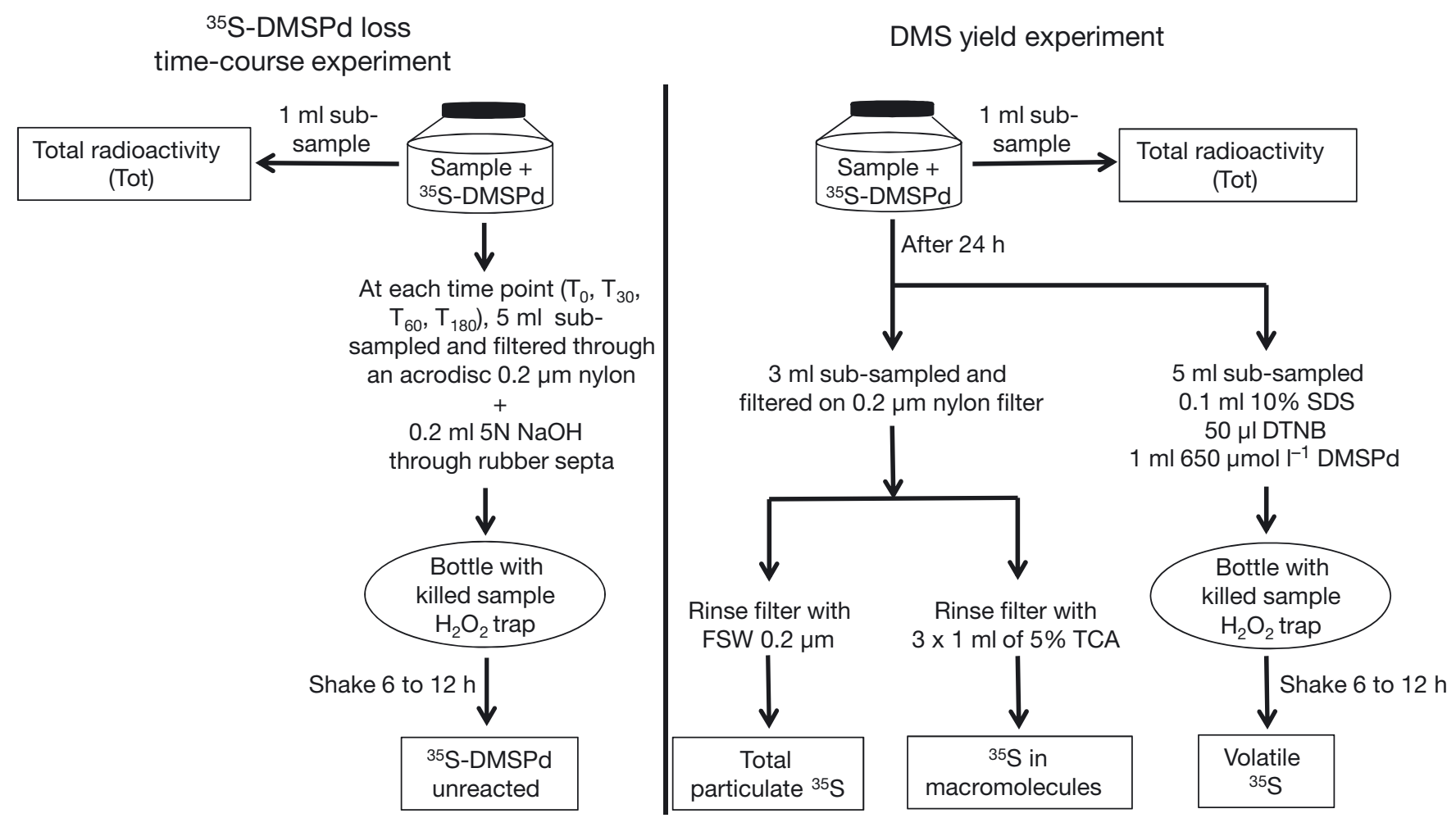

Fig. 2. Methods used to determine microbial dissolved dimethylsulfoniopropionate (DMSPd) metabolism after incubation of seawater samples with ${ }^{35} \mathrm{~S}-\mathrm{DMSPd}$

(0.2 $\mu \mathrm{m}$ nylon membrane). The algal and bacterial DMSPd loss rate constant $\left(\mathrm{k}_{\mathrm{DMSPd}}\right)$ was determined using the slope of the natural logarithm transformed radioactivity of unreacted ${ }^{35} \mathrm{~S}$ DMSPd during this $3 \mathrm{~h}$ time-course experiment. Second, a modified version of DMS yield experiments adapted from the method described by Merzouk et al. (2008) was used. Bottles were injected with ca. $100 \mathrm{nmol} \mathrm{l^{-1 }}$ of dimethyldisulfide (DMDS) (Galí et al. 2011), an effective inhibitor of bacterial DMS consumption (Simó et al. 2000), and amended with ${ }^{35}$ S-DMSPd. These bottles were incubated in the dark at $-1^{\circ} \mathrm{C}$ for $24 \mathrm{~h}$. After this period, subsamples were taken to determine the particulate, trichloroacetic acid (TCA)-insoluble macromolecules and dissolved non-volatile fractions. At the same time, a $5 \mathrm{ml}$ subsample was taken to determine volatile ${ }^{35} \mathrm{~S}$. Ellman's reagent (dithionitrobenzoic acid [DTNB]) in Trizma hydrochloride buffer was used to bind methanethiol (MeSH), another volatile product of DMSP degradation, to obtain only ${ }^{35} \mathrm{~S}-\mathrm{DMS}$ in the volatile fraction. Radioactivity in all subsamples was measured at Laval University using a QuantaSmart $^{\text {TM }}$ TriCarb 2910 TR liquid scintillation analyzer. The methods described above enabled the determination of the following 5 parameters: (1) the algal and bacterial DMSPd loss rate constant ( $\left.\mathrm{k}_{\mathrm{DMSPd}}\right)$ with units $\mathrm{d}^{-1}$, (2) the algal and bacterial DMSPd consumption rate (DMSPd concentration $\times \mathrm{k}_{\mathrm{DMSPd}}$ ) with units nmol $\mathrm{l}^{-1} \mathrm{~d}^{-1}$, (3) the bacterial DMS yield (percentage of ${ }^{35} \mathrm{~S}$ DMSPd added that was recovered as volatile ${ }^{35} \mathrm{~S}$ after $24 \mathrm{~h}$ of incubation) with units as \%, (4) the bacterial gross DMS production rate (algal and bacterial DMSPd uptake rate $\times$ DMS yield) with units nmol $\mathrm{l}^{-1} \mathrm{~d}^{-1}$ and (5) the algal and bacterial DMSP-S assimilation efficiency (percentage of ${ }^{35} \mathrm{~S}$ DMSPd added that was recovered into TCAinsoluble macromolecules) with units as \%. Some diatoms as well as the cyanobacteria Synechococcus and Prochlorococcus can take up and accumulate DMSPd (Vila-Costa et al. 2006, del Valle et al. 2012, Ruiz-González et al. 2012b), but there is no evidence suggesting that they may cleave DMSPd into DMS. Thus, we consider the $\mathrm{k}_{\mathrm{DMSPd}}$ and DMSPd uptake rate as algal and bacterial, while the DMS yield and DMS production rate are assumed to be mostly bacterial. We cannot exclude the possibility that DMSPd conversion to DMS via free DMSP-lyases may have taken place during our measurements. We believe, however, that this was a minor process compared with bacterial cleavage. First, ice diatoms were responsible for most of the biomass and DMSP found in the ice as well as in the water column during the 
melting period in our study. To date, DMSP-lyases have not been observed in diatoms (Stefels et al. 2007). Hence, the release of ice diatoms in the water column and their subsequent lysis or grazing should not have resulted in a large increase in free DMSP-lyases. Second, the few existing measurements from studies conducted at lower latitudes also suggest that this is a minor pathway. For example, Scarratt et al. (2000) reported that free-living bacteria and free enzymes accounted for only a small fraction of the total DMS production $(<10 \%)$. Therefore, the conversion of DMSPd to DMS via free DMSP-lyases was most probably negligible in our study.

\section{Statistical analysis}

Model I linear regressions were used to determine biological rates during the incubations (Sokal \& Rohlf 1995). The normality of the distributions of abiotic and biotic variables was assessed using the Shapiro-Wilk test. Relationships between variables normally distributed were determined with Pearson's linear correlations (r). Model II linear regressions (reduced major axis) were used to determine the relationship between DMSP-S assimilation into particles and bacterial abundance. Statistical tests were carried out using JMP® 10.0 Software, and the graphics were produced using SigmaPlot 12.5 (Systat Software).

\section{RESULTS}

\section{The physical environment}

Variations in the physical characteristics of the snow, ice and water column are presented in Fig. 3. The daily averaged air temperature of $-5.19^{\circ} \mathrm{C}$ at the beginning of the sampling period began to increase on 26 May and reached above $0^{\circ} \mathrm{C}$ on 2 June (Fig. 3a). The thickness of the snow cover varied between 13 and $24 \mathrm{~cm}$ from the beginning of the sampling until 4 June, when it decreased sharply to $8 \mathrm{~cm}$ on 6 June and
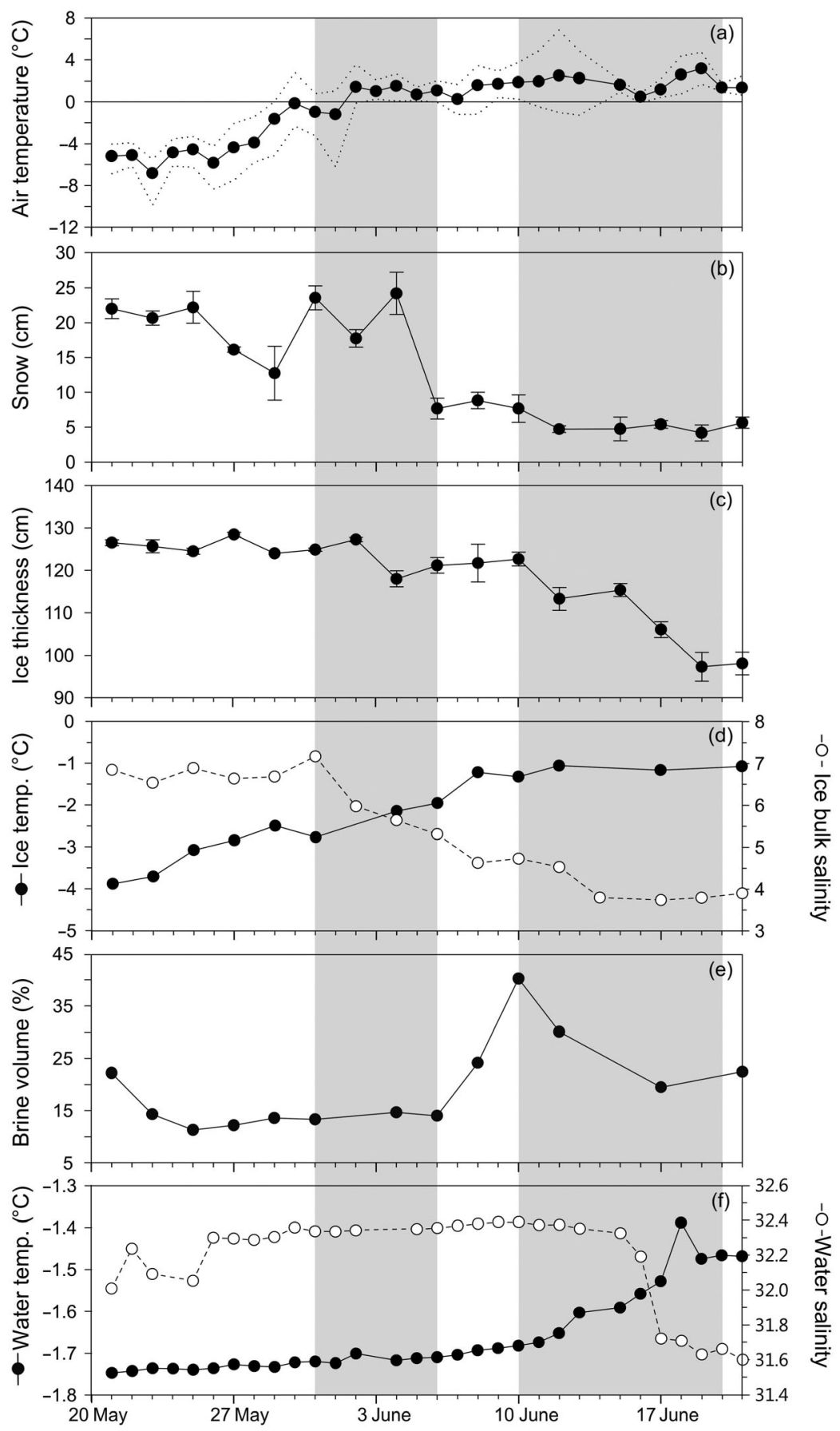

Fig. 3. Time series of (a) air temperature, (b) snow depth, (c) ice thickness, (d) average of ice temperature and bulk salinity over the entire ice core, (e) average of brine volume over the entire ice core, and (f) seawater temperature and salinity at $0.5 \mathrm{~m}$ under the ice in Resolute Passage during spring of 2012. The grey zones indicate the melt events. In (a), daily average values and ranges are shown. In (b) and (c), vertical bars are the standard deviations of the averages

remained at this low level until the end of the sampling (Fig. 3b). Ice thickness remained stable at ca. $125 \mathrm{~cm}$ from the beginning of the sampling until 2 
June when it decreased abruptly to $118 \mathrm{~cm}$. After 10 June, the ice thickness decreased to reach ca. $98 \mathrm{~cm}$ at the end of the sampling period (Fig. 3c). The ice broke up $14 \mathrm{~d}$ later on 5 July. The temperature averaged over the entire ice core started at $-3.88^{\circ} \mathrm{C}$, increased regularly to reach $-1.21^{\circ} \mathrm{C}$ on 8 June and remained stable until the end of the sampling (Fig. 3d). The ice bulk salinity averaged over the entire ice core was 6.85 from the start of the sampling until 31 May, when it decreased gradually to 3.74 on 14 June, and remained stable until the end of the sampling period (Fig. 3d). The brine volume averaged over the entire ice core was $\sim 15 \%$ at the beginning of the sampling, increased abruptly to $40 \%$ between 6 and 10 June and decreased gradually to stabilize at $20 \%$ on 17 June and thereafter (Fig. 3e). Brine volumes were thus always higher than $5 \%$, suggesting that the sea ice was permeable during the entire sampling period (Pringle et al. 2009). Seawater temperature at $0.5 \mathrm{~m}$ under the ice increased gradually from $-1.75^{\circ} \mathrm{C}$ at the beginning of the sampling period to $-1.68^{\circ} \mathrm{C}$ on 10 June, increased more rapidly to reach $-1.39^{\circ} \mathrm{C}$ on 18 June and remained at this temperature until the end of the sampling (Fig. 3f). Seawater salinity at $0.5 \mathrm{~m}$ under the ice remained relatively constant at around 32.3 until 15 June, then decreased abruptly to 31.7 in $2 \mathrm{~d}$ and remained relatively stable for the rest of the sampling period (Fig. 3f).

Shaded areas in Fig. 3 delineate the 2 major melt events that took place during our sampling period. The first one, between 31 May and 6 June, was characterized by the loss of most of the snow cover and a minor decrease in ice thickness (Fig. 3b,c). Bulk ice salinity decreased from 7.17 to 5.31 (Fig. 3d), indicating brine release during this event. The second melting event, from 10 June to the end of the sampling period, was characterized by a more substantial decrease in ice thickness (from 123 to $98 \mathrm{~cm}$ ) and by a warming and decrease in salinity of the water under the ice (Fig. 3c,f). Both events coincided with either an import or a local production of organic matter in the water column under the ice, which triggered changes in algal and bacterial DMSPd metabolism, as shown in Fig. 4.

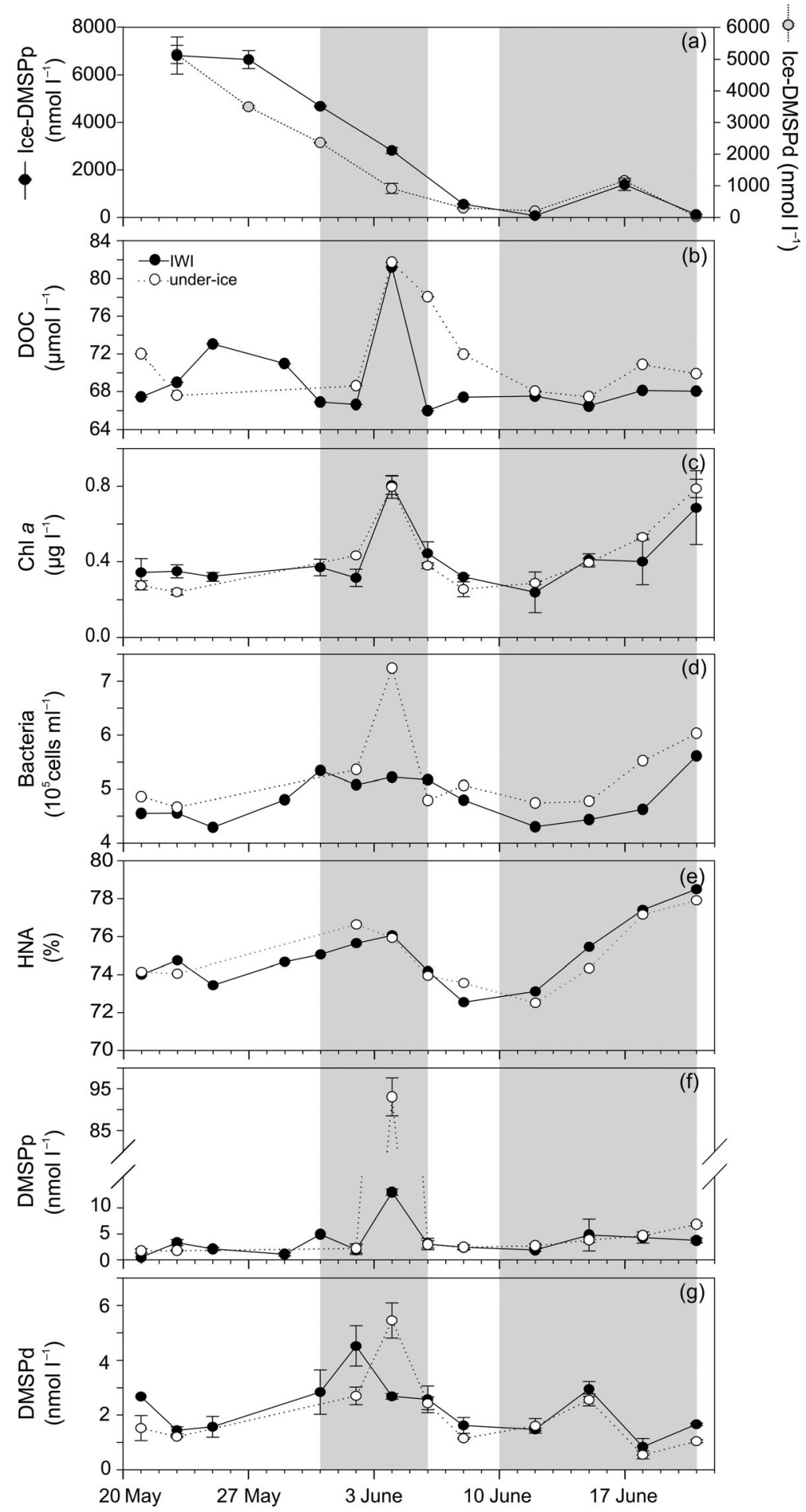

Fig. 4. Time series of (a) DMSPp and DMSPd in the bottom $3 \mathrm{~cm}$ of sea ice, (b) dissolved organic carbon (DOC), (c) chlorophyll a (Chl a), (d) bacterial abundance, (e) percentage of bacterial cells with high nucleic acid content (HNA), (f) DMSPp and (g) DMSPd at the ice-water interface (IWI) (black dots) and in the water $0.5 \mathrm{~m}$ under the ice (under-ice) (white dots) in Resolute Passage during spring of 2012. The grey zones indicate the melt events. In $(\mathrm{a}, \mathrm{b}, \mathrm{c}, \mathrm{f}, \mathrm{g})$, error bars: $\mathrm{SD}$ 


\section{Biological and chemical characteristics of bottom sea ice and surface waters}

Bottom ice DMSPp concentrations were ca. $6800 \mathrm{nmol} \mathrm{l}^{-1}$ at the beginning of the sampling period and decreased progressively to reach $556 \mathrm{nmol} \mathrm{l}^{-1}$ on 8 June. They then remained relatively low until the end of the sampling period except for a slightly higher value of $1386 \mathrm{nmol} \mathrm{l}^{-1}$ on 17 June (Fig. 4a). Bottom ice DMSPd concentrations closely followed the DMSPp variations, with values of $5087 \mathrm{nmol} \mathrm{l}^{-1}$ at the beginning of the sampling and a decrease down to $290 \mathrm{nmol} \mathrm{l}^{-1}$ on 8 June. After 8 June, the DMSPd concentrations remained relatively stable until the end of the sampling period except for a peak of $1160 \mathrm{nmol} \mathrm{l}^{-1}$ measured on 17 June coinciding with the DMSPp peak mentioned previously. During this study, bottom ice chl a concentrations followed the same trend from 2500 to $45 \mu \mathrm{g} \mathrm{l}^{-1}$ as the one observed for bottom ice DMSPp and DMSPd (C. J. Mundy unpubl. data).

In surface water, DOC concentrations var-

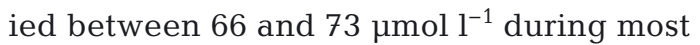
of the sampling period, except between 4 and 7 June when they increased to $83 \mu \mathrm{mol} \mathrm{l^{-1 }}$ at both sampling depths (i.e. at the ice water-interface and $0.5 \mathrm{~m}$ under the ice; Fig. 4b). Chl a concentrations remained between 0.2 and $0.4 \mu \mathrm{g} \mathrm{l}^{-1}$ at both sampling depths during the whole sampling period except for a sharp and short-lived increase to $0.8 \mu \mathrm{g} \mathrm{l}^{-1}$ on 4 June and a more gradual increase to $0.8 \mathrm{\mu g}^{-1}$ between 12 June and the end of the sampling period (Fig. 4c). The bacterial abundance followed more or less the same trend as chl $a$, with background values around $5 \times 10^{5} \mathrm{cells} \mathrm{ml}^{-1}$ and a peak of $7.3 \times 10^{5}$ cells ml $^{-1}$ on 4 June (at the ice-water interface only) and a more gradual increase to a maximum of $6.1 \times$ $10^{5}$ cells $\mathrm{ml}^{-1}$ (at both depths) toward the end of the sampling period (Fig. 4d). HNA bacteria comprised between 72 and $78 \%$ of the total prokaryotes, with higher values coinciding with the 2 periods of high bacterial abundance (Fig. 4e). DMSPp concentrations generally varied between 0.5 and $6.8 \mathrm{nmol} \mathrm{l}^{-1}$ with a single peak measured on 4 June at the icewater interface $\left(13 \mathrm{nmol} \mathrm{l}^{-1}\right)$ and at $0.5 \mathrm{~m}$ under the ice $\left(93 \mathrm{nmol} \mathrm{l}^{-1}\right)$ (Fig. 4f). DMSPd concentrations
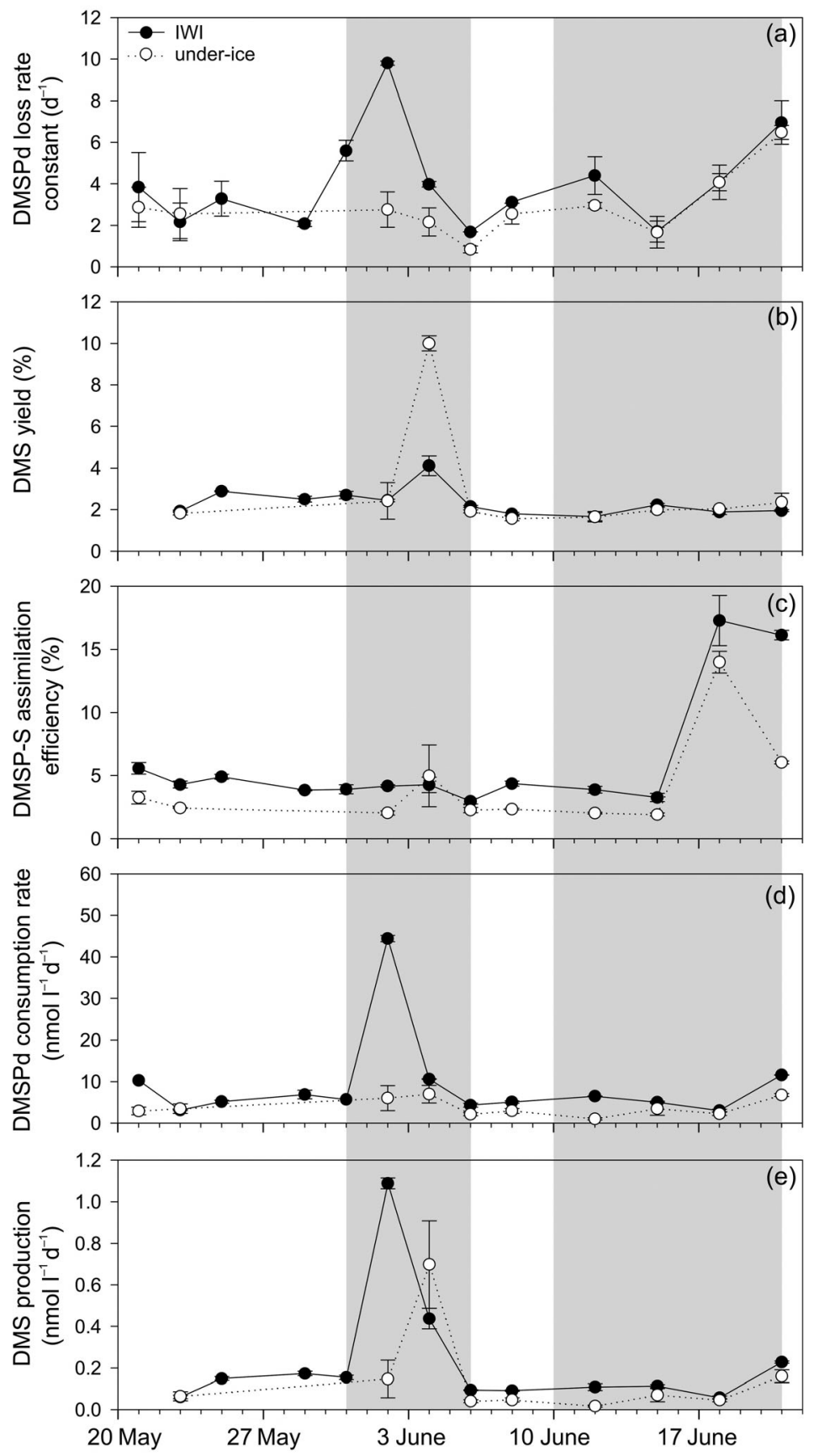

Fig. 5. Time series of (a) DMSPd loss rate constant, (b) DMS yield, (c) DMSP-S assimilation efficiency into macromolecules, (d) DMSPd consumption rate, and (e) DMS production rate at the ice-water interface (IWI) (black dots) and in the water $0.5 \mathrm{~m}$ under the ice (under-ice) (white dots) in Resolute Passage during spring of 2012. The grey zones indicate the melt events. Error bars: SD

ranged from 0.5 to $2.95 \mathrm{nmol} \mathrm{l}^{-1}$, except between 31 May and 4 June when they reached $4.5 \mathrm{nmol} \mathrm{l}^{-1}$ at the ice-water interface and $5.5 \mathrm{nmol} \mathrm{l}^{-1}$ at $0.5 \mathrm{~m}$ under the ice (Fig. 4g). 


\section{DMSPd algal and bacterial metabolism at the ice- water interface and at $0.5 \mathrm{~m}$ under the ice}

At the ice-water interface, the algal and bacterial DMSPd loss rate constant ( $\mathrm{k}_{\text {DMSPd }}$ ) varied between 1.6 and $5.6 \mathrm{~d}^{-1}$, except during the melt event and the onset of under-ice phytoplankton growth when it increased to 9.8 and $7.0 \mathrm{~d}^{-1}$, respectively (Fig. 5a). At $0.5 \mathrm{~m}$ under the ice, $\mathrm{k}_{\mathrm{DMSPd}}$ values remained around 0.8 to $4.1 \mathrm{~d}^{-1}$ during the first melt event but increased to $6.5 \mathrm{~d}^{-1}$ during the onset of under-ice phytoplankton growth as observed at the ice-water interface.

The DMS yields remained extremely low and stable during most of the sampling period at both sampling depths, with values varying between 1.6 and $2.9 \%$ (Fig. 5b). Higher DMS yields were only measured on 4 June during the first melt event with values of 4.1 and $10 \%$ at the ice-water interface and $0.5 \mathrm{~m}$ under the ice, respectively. The DMSP-S assimilation efficiency was low and stable (ca. $4 \%$ ) at both sampling depths until 15 June, when it increased abruptly to reach $17 \%$ on 18 June (Fig. 5c). Afterward, the DMSP-S assimilation efficiency remained high at the ice-water interface but decreased to $6 \%$ at $0.5 \mathrm{~m}$ under the ice. The algal and bacterial DMSPd consumption rates were low (ca. $5 \mathrm{nmol} \mathrm{l}^{-1} \mathrm{~d}^{-1}$ ) and stable at both depths during the sampling period except a single short-lived peak of $44.4 \mathrm{nmol} \mathrm{l}^{-1} \mathrm{~d}^{-1}$ measured on 2 June at the ice-water interface only (Fig. 5d). Gross DMS production rates were $<0.2 \mathrm{nmol} \mathrm{l}^{-1} \mathrm{~d}^{-1}$ during most of the sampling period, except on 2 and 4 June when rates peaked at $1.09 \mathrm{nmol} \mathrm{l}^{-1} \mathrm{~d}^{-1}$ and $0.69 \mathrm{nmol} \mathrm{l}^{-1} \mathrm{~d}^{-1}$ at the ice-water interface and at $0.5 \mathrm{~m}$ under the ice, respectively (Fig. 5e).

\section{DISCUSSION}

This is the first time-series showing the response of the under-ice algal and bacterial assemblage to organic matter and DMSP released from the ice or produced by under-ice phytoplankton growth in the Arctic during the melt season. Our 4 wk sampling period captured 1 major ice-DMSP release event that was triggered by brine drainage and flushing resulting from the combined effect of snow and ice melt. This first event was followed a few days later by the onset of under-ice phytoplankton growth, probably indicating the initiation of an under-ice bloom as previously observed in this area (Galindo et al. 2014, Mundy et al. 2014). The phytoplankton growth probably resulted from the combined effects of higher light transmittance through the sea ice and an increase in water column stratification (C. J. Mundy unpubl. data). Both events resulted in an increase in the abundance of autotrophic and heterotrophic cells at the ice-water interface and at $0.5 \mathrm{~m}$ under the ice and in specific alterations of the algal and bacterial DMSPd metabolism.

\section{Response of the under-ice algal and bacterial assemblage to bottom ice organic matter release}

At the end of May and during the first week of June, the successive effects of snow and ice melt resulted in a progressive release of most of the particulate and dissolved DMSP present in the bottom of the sea ice. The decrease in average ice bulk salinity (Fig. 3d) and brine salinity through the ice core during this period (data not shown) confirmed the presence of brine movements through drainage, and potentially, flushing. Furthermore, the minor loss of ice thickness was likely associated with the warming of sea ice due to the increase of light absorption in first-year sea ice following the snow melt and with an erosion of the bottom ice habitat by under-ice currents (data not shown). These mechanisms are known to cause the release of organic matter from the sea ice into the water column (Lavoie et al. 2005, Mundy et al. 2005, Polashenski et al. 2012).

The influence of bottom ice organic-matter release was first detected in the water column on 2 June by an increase in DMSPd at the ice-water interface. This DMSPd input coincided with an increase in $\mathrm{k}_{\mathrm{DMSPd}}$ by $472 \%$ in $4 \mathrm{~d}$ and algal and bacterial DMSP consumption by $777 \%$ in $2 \mathrm{~d}$ in this thin layer. Bacterial production in ice-covered waters is strongly limited by the supply of organic carbon during spring in the Arctic (Garneau et al. 2008). Hence, the increase in $\mathrm{k}_{\text {DMSPd }}$ probably resulted from the stimulation of the pelagic bacterial activity by the input of organic matter (including DMSPd) from the sea ice, as suggested by the slight increase in their abundance during this first melt period (Fig. 4d). This interpretation is further supported by the gradual increase in bacterial abundance accompanied by the increase in relative abundance of HNA cells, generally considered as an index of the proportion of actively growing bacteria (Lebaron et al. 2001, but see also Bouvier et al. 2007). Two recent studies report $k_{\text {DMSPd }}$ values varying between 0.6 and $3.3 \mathrm{~d}^{-1}$ in Arctic ice-free waters in late summer and autumn (Luce et al. 2011, MotardCôté et al. 2012). These $k_{\text {DMSPd }}$ values are in the same range as those measured throughout most of the 
sampling period under the ice, but are much lower than the peak value of $11 \mathrm{~d}^{-1}$ measured on 2 June. Our maximum $\mathrm{k}_{\mathrm{DMSPd}}$ value is, however, comparable with the peak values measured at lower latitudes, such as the Mediterranean Sea (up to $6.2 \mathrm{~d}^{-1}$; VilaCosta et al. 2008b), the Northwest Atlantic (up to $4.1 \mathrm{~d}^{-1}$; Lizotte et al. 2012) and the Northeast Pacific (up to $22.1 \mathrm{~d}^{-1}$; Royer et al. 2010). These results show that the release of organic matter and DMSPd from the sea ice may result in a short (maximum of $4 \mathrm{~d}$ based on our sampling frequency) but important increase in algal and bacterial DMSPd consumption rate at the ice-water interface, leading to a rapid turnover of the DMSPd released from the sea ice.

As seen in Fig. 5b, the DMS yield of the bacteria present at the ice-water interface was not affected by this initial release of DMSPd from the ice and the associated increase in DMSPd consumption rate. The DMS yield remained low (ca. $2.4 \%$ ), showing that the bacteria continue to use DMSP as a carbon and sulfur source during the large bottom ice organic-matter release event. This result is surprising considering that the release of organic matter and DMSPd from the brines probably resulted in variations in the quality (proportion of labile dissolved organic carbon and sulfur) of the dissolved organic matter available for bacteria. For example, DOC and DMSPd concentrations of $228 \mathrm{mmol} \mathrm{l}^{-1}$ and $19.5 \mathrm{nmol}^{-1}$ were measured in brines on 31 May. The efficiency of bacterial DMSP-S assimilation into macromolecules at the icewater interface also remained low, at ca. $5 \%$, during the release of bottom ice organic matter. The stability of these 2 metabolic indicators suggests that a large portion of the sulfur obtained from DMSP during this event was rapidly $(<3 \mathrm{~h})$ excreted as a non-volatile ${ }^{35}$ S-product. Vila-Costa et al. (2014) similarly reported high losses of DMSP-S taken up by bacteria and converted to the non-volatile ${ }^{35} \mathrm{~S}$-product during a study in the Sargasso Sea. Because the ${ }^{35} \mathrm{~S}-\mathrm{DMSP}$ tracer is labeled on the S moiety and the C-DMSP can be significantly respired (Vila-Costa et al. 2010), the authors attributed this specific DMSP metabolism as an indication of the relevance of $\mathrm{C}$ availability to bacteria in modulating DMSP fate. In spite of the low and unchanged DMS yield, the initial response of the bacterial community measured at the ice-water interface on 2 June resulted in an important (727\% in $2 \mathrm{~d}$ ) but short-lived increase in DMS gross production (Fig. 5e). Since DMSPd conversion into DMS by free DMSP-lyases was likely negligible in our study as explained in 'Determination of algal and bacterial DMSPd metabolism in surface waters', the increase in DMS production was most likely driven by the increase in DMSPd concentrations and $\mathrm{k}_{\mathrm{DMSPd}}$, hence bacterial DMSPd consumption and metabolism.

The initial detection of the effect of bottom ice organic matter release at the ice-water interface on 2 June due to brine drainage was followed $2 \mathrm{~d}$ later by marked increases in chl $a$ and DMSPp at both the icewater interface and $0.5 \mathrm{~m}$ under the ice. This second release of organic material from the sea ice coincided with ice melt. At that time, bacterial abundance increased at $0.5 \mathrm{~m}$ under the ice, probably reflecting an input of sympagic bacteria associated with algae and particles from the bottom ice. Bacteria responded differently to this ice-melt-induced large input of organic matter. This ice-melt event coincided with a decrease in $\mathrm{k}_{\mathrm{DMSPd}}$ but a sharp increase in DMS yield (Fig. 5a,b). On one hand, the decrease in $\mathrm{k}_{\text {DMSPd }}$ suggests that DMSP represented a less important substrate for the bacteria during that period. The large peaks in DOC associated with the release of chl $a$ and DMSP from the sea ice indicate that the heterotrophic bacteria had access to a more substantial pool of organic carbon following this major release of organic matter from the bottom ice and that the supply exceeded their requirements during the event (Fig. 4b). On the other hand, the important increase in DMS yield (by $411 \%$ ) measured at $0.5 \mathrm{~m}$ under the ice indicates that the bacteria needed less sulfur from DMSP to support their growth. Assuming that DMS yields vary mostly as a function of the bacterial sulfur requirement and the availability of organic sulfur (Kiene et al. 2000, Pinhassi et al. 2005, Levasseur et al. 2006), this peak value suggests that the cells had access to other labile organic sulfur (e.g. methionine, cysteine), probably of sea ice origin, during this period.

Overall, the low DMS yields measured during most of our sampling period indicate that under-ice bacteria were generally not efficient at converting DMSP into DMS during the spring season. Our results suggest that only dissolved organic matter (DOM)-rich conditions, such as those occurring during the release of organic matter from the bottom ice, may lead to high DMS yields. Other studies conducted in the Arctic but during ice-free conditions have reported DMS yields varying between 4 and $31 \%$, with higher values also measured in water masses rich in chl a and DMSPp (Luce et al. 2011, Motard-Côté et al. 2012). Our results suggest that elevated DMS yields are probably short-lived events under the sea ice, coinciding with initial ice melt and the associated release of ice algae in the water column.

As observed at the ice-water interface $2 \mathrm{~d}$ earlier, the major release of chl $a$ and DMSPp from the ice 
also resulted in an increase in microbial DMS production by $467 \%$ in 2 d. However, in contrast with the previous event, the enhancement resulted almost entirely from the increase in DMS yield. The difference in the response observed between 2 June (increase in $\mathrm{k}_{\mathrm{DMSPd}}$ ) and 4 June (increase in DMS yield) may reflect a change in the origin of the bacterial assemblage and/or the abundance of bacteria. The brine-release event that took place between 31 May and 2 June stimulated bacterial activity of the substrate-limited pelagic community underneath the ice. The increases of DMSPd concentrations and DMSPd loss rate constants resulted in the increase of DMS production at the ice-water interface. In contrast, the sea ice melting that took place between 2 and 4 June resulted in the major release of ice algae and its associated DMSP and sympagic bacteria. The higher DMS yield measured at that time suggests that the bacterial assemblage, likely of ice origin, was acclimated to an environment already rich in DMSPd. The sinking of ice algae and local currents can explain the propagation of the signal down to $0.5 \mathrm{~m}$ under the ice. The increase in DMS yield also translated into an increase in DMS production at $0.5 \mathrm{~m}$ under the ice. It is interesting to note that the maximum DMS production rates measured under the ice during the release of the bottom ice algal community (up to $1 \mathrm{nmol} \mathrm{l}^{-1} \mathrm{~d}^{-1}$ ) were 2 - to 3 -fold higher than those reported for the same area in summer in open waters (0.31 nmol l-1 $\mathrm{d}^{-1}$; Motard-Côté et al. 2012). These high production rates can probably only be reached in DOM-rich conditions such as those encountered in brine channels at the end of the ice algal bloom.

The increase in DMS production following the release of organic matter and DMSPd from first-year sea ice could represent a non-negligible contribution to the under-ice water column DMS during a period when DMS levels are usually extremely low (Levasseur et al. 1994, Bouillon et al. 2002). The fate of this DMS is still to be determined, but our general understanding of the DMS cycle allows some speculations. The 3 known sinks for DMS are photo-oxidation, bacterial consumption and ventilation. Photooxidation should be minimal underneath the ice due to the prevailing low irradiance in general and UV radiation in particular (Winther et al. 2004, Nicolaus et al. 2013). DMS bacterial consumption likely takes place, but, as observed at lower latitudes, DMSconsuming bacteria generally take some time to react to a pulse in DMS, allowing a temporary buildup of the DMS reservoir. We can thus speculate that the rapid response of the DMSP-consuming algae and bacteria to the DMSPd pulse from the ice will result in a temporary increase in DMS concentrations in the water column. As sea ice was permeable during our study, DMS may have escaped through the ice. Large amounts of DMS emanating from melting sea ice have been directly measured in the Antarctic (Zemmelink et al. 2008) and inferred from satellite records of aerosol optical depth over the sea ice during spring in the Arctic (Gabric et al. 2005). The DMS produced under the ice may also be ventilated in leads and at the ice edge during ice break-up and retreat. However, the existence of a stratified melt layer associated with the melting ice cover would have limited DMS diffusion through the ice cover. Therefore, accumulation of DMS in the under-ice environment could further contribute to the high DMS concentrations reported by few studies in the marginal ice zone in the Arctic (Matrai \& Vernet 1997, Galí \& Simó 2010). These ice-related processes should eventually be included in Arctic DMS models such as those developed by Qu \& Gabric (2010) and Humphries et al. (2012). DMS production underneath the sea ice as a result of DMSP released from the ice will probably become more important in the future as first-year sea ice increases its prevalence in the Arctic as a result of climate warming (Stroeve et al. 2012).

\section{Response of the algal and bacterial assemblage to the onset of under-ice phytoplankton growth}

The increase in surface chl a measured during the last week of the sampling period likely marked the onset of under-ice phytoplankton growth (C. J. Mundy unpubl. data). Under-ice blooms have been observed and fully described in this area in the past (Galindo et al. 2014, Mundy et al. 2014). The increase in phytoplankton biomass coincided with an increase in bacterial abundance and HNA cells, suggesting that the bacteria benefitted from an increase in DOM during this period. The under-ice phytoplankton likely grew as a result of increasing under-ice irradiance due to the loss of the snow cover and development of melt ponds and as a result of an increase in water column stratification due to the melting of the ice (Fig. 2). One of the salient features of the underice phytoplankton growth was the absence of any increase in DMSPp despite the increase in chl a that was of the same magnitude (ca. $0.4 \mu \mathrm{g} \mathrm{l}^{-1}$ ) as that associated with the release of organic matter from the bottom sea ice observed earlier. This difference translated into widely different DMSPp/chl a ratios 
for the 2 biomass peaks: 16 to $117 \mathrm{nmol} \mathrm{\mu g}^{-1}$ for ice algae released in the water column and 5 to $11 \mathrm{nmol}$ ${\mu \mathrm{g}^{-1}}$ for the under-ice phytoplankton. The low ratios measured during the growth of phytoplankton are similar to the ratios ranging from 2.6 to $19.6 \mathrm{nmol}$

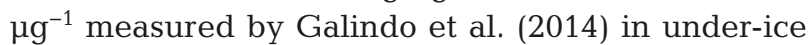
blooms dominated by centric and pennate diatoms in the same study area during previous years. The ratio of $16 \mathrm{nmol} \mathrm{g} \mathrm{g}^{-1}$ measured at the ice-water interface is also in the range (2.1 to 28.4) of those reported by Galindo et al. (2014) for released ice algae in this region. However, the ratio of $117 \mathrm{nmol} \mathrm{\mu g}^{-1}$ measured at $0.5 \mathrm{~m} 2 \mathrm{~d}$ later is unexpectedly high. Its concurrence with the maximum bacterial abundance value suggests that part of the DMSPp could have been associated with the heterotrophs. In support of this hypothesis, Wolfe (1996) measured intracellular DMSP concentrations in bacterial cultures as high as $100 \mathrm{mmol}^{-1}$. Assuming that the bacteria present at $0.5 \mathrm{~m}$ under the ice had the same DMSP quota and considering a bacterial diameter of $0.8 \mu \mathrm{m}$ as used by Wolfe (1996), we calculated that bacteria may have contributed to the DMSPp pool by $19.55 \mathrm{nmol} \mathrm{l}^{-1}$, explaining up to $21 \%$ of the increase in DMSPp. Since DMSP and its cleavage products, DMS and acrylic acid, have been shown to act as grazing deterrents for zooplankton (Wolfe et al. 1997, Strom et al. 2003), the high DMSP concentrations may also reflect a physiological response of the algae to the high zooplankton grazing prevailing under the ice during this time of the year (Runge \& Ingram 1991, Michel et al. 1996).

As observed during the release of organic matter from the bottom sea ice, the onset of under-ice phytoplankton growth stimulated the capacity of the microbial community to use DMSPd. $\mathrm{k}_{\mathrm{DMSPd}}$ increased by $409 \%$ in $6 \mathrm{~d}$, following the increase in bacterial abundance and the percentage of actively growing bacterial cells (HNA cells). These results show that bacterial growth can respond promptly to the growth of under-ice phytoplankton, even in its initial phase. This in turn suggests that a significant portion of primary production was exuded by the exponentially growing algal cells. Gosselin et al. (1997) observed along a summer transect, from the Chukchi Sea to the Nansen Basin via the North Pole, that generally $<20 \%$ of primary production was released as DOC, except in the Canadian Basin, where it ranged from 31 to $65 \%$. During the onset of under-ice phytoplankton growth, bacterial DMSP-S assimilation efficiency into macromolecules increased by $534 \%$ in $3 \mathrm{~d}$ following the increase in bacterial abundance (Fig. 6; $r=0.76, p<0.05$ ). Considering that DMSP can provide most of the bacterial sulfur for protein synthesis (Malmstrom et al. 2004), this increase probably reflects the higher requirement for sulfur of the actively growing bacteria (Reisch et al. 2011). DMS yields remained low (ca. 2.5\%) during the onset of under-ice phytoplankton growth, also reflecting the high sulfur requirement of the actively growing bacteria. Previous studies have shown that variations in DMSP-S assimilation may also result from a physiological response of the bacteria due to a change in the relative contribution of DMSP to the total dissolved organic sulfur pool (Lizotte et al. 2009) or a modification of the taxonomic composition of the bacterial assemblage in response to qualitative changes in DOM (Cottrell \& Kirchman 2000). These mechanisms are not mutually exclusive and could have all contributed to the observed increase in DMSP-S assimilation during the onset of under-ice phytoplankton growth.

In contrast with the bottom ice organic matter release event, changes in DMSPd microbial metabolism associated with the onset of under-ice phytoplankton growth did not result in a significant increase in gross bacterial DMS production (Fig. 5e). This is not unexpected considering that high biological gross DMS production generally takes place during the senescent phase of blooms when DOC concentrations are high (Kwint \& Kramer 1995, Gosselin et al. 1997, Zhuang et al. 2011). Surveys of the different development phases of under-ice blooms will be required to better quantify their potential contribution to the water column DMS reservoir in spring.

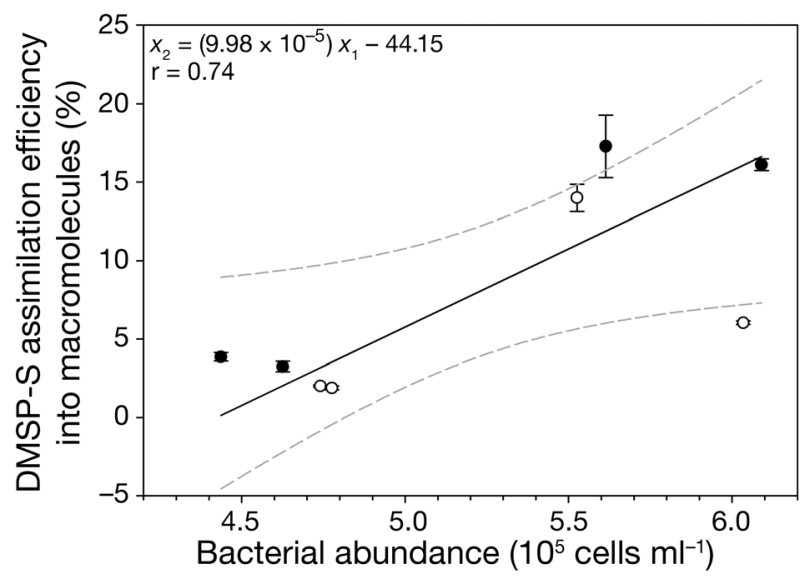

Fig. 6. Model II linear regression between DMSP-S assimilation efficiency into particles and bacterial abundance at both sampling depths after 10 June: ice-water interface (black dots) and water $0.50 \mathrm{~m}$ under the ice (white dots). The grey dashed lines indicate the $95 \%$ confidence interval. Vertical bars are the standard deviations of the average 


\section{CONCLUSIONS}

Our study characterized for the first time the impact of sea ice brine drainage and ice melting on the microbial DMSP metabolism under the ice and the early response of the bacteria to the onset of under-ice phytoplankton growth. The results highlight that bacteria thriving under first-year sea ice in spring have their DMSP metabolism rapidly $(<4 \mathrm{~d})$ stimulated by the release of DOC and DMSP from the ice during snow and ice melt events as well as by the onset of under-ice phytoplankton growth. Despite the short-lived nature of these release events (a few days), the large extent of first-year sea ice in the Arctic suggests that the DMS production associated with these events should have a significant impact on the annual DMS production. The onset of the under-ice phytoplankton growth did not stimulate DMS production, an expected result considering that DMS peaks are usually associated with the senescent phase of blooms in open waters (e.g. Leck et al. 1990, Matrai \& Keller 1993, Kwint \& Kramer 1995). The frequency and coverage of these under-ice blooms are expected to increase with climate warming and the replacement of multi-year ice by first-year ice (Arrigo et al. 2012, Boetius et al. 2013, Matrai \& Apollonio 2013). Thus, it becomes important to characterize the net DMS production during the different stages of the under-ice bloom development.

Acknowledgements. This work was supported by the Natural Sciences and Engineering Research Council of Canada (NSERC), Fonds de recherche du Québec - Nature et technologies (FRQNT), Canada Economic Development and the Polar Continental Shelf Program (PCSP) of Natural Resources Canada. R.P.K. acknowledges the support of the National Science Foundation (grant OCE-0928968). The authors thank Marjolaine Blais, Alexis Burt, Mathew Gale and Nicolas-Xavier Geilfus for assistance in the field and Jessie Motard-Côté for ${ }^{35} \mathrm{~S}$-DMSP technique assistance. We also thank Flavienne Bruyant and Joannie Ferland for assistance with the liquid scintillation analyzer. We are grateful to Mélanie Simard for the DOC analysis (ISMER), Dennis A. Hansell and Wenhao Chen for providing the DOC Consensus Reference Materials (Rosenstiel School of Marine \& Atmosphere Science, University of Miami, Miami, Florida, USA), Claude Belzile, Pascal Rioux and Marjolaine Blais for flow cytometry analysis (ISMER), Pascal Guillot for CTD data processing (Québec-Océan) and Bruce Johnson (T. Papakyriakou laboratory, University of Manitoba) for air temperature data processing. We also thank the 2 anonymous reviewers for their most helpful suggestions for improving this paper. This is a contribution to the research programs of ArcticNet, Québec-Océan, ISMER, Arctic Science Partnership (ASP) and the Canada Excellence Research Chair unit at the Centre for Earth Observation Science.

\section{LITERATURE CITED}

Arrigo KR, Perovich DK, Pickart RS, Brown ZW and others (2012) Massive phytoplankton blooms under Arctic sea ice. Science 336:1408

Bates SS, Cota FC (1986) Fluorescence induction and photosynthetic responses of Arctic ice algae to sample treatment and salinity. J Phycol 22:421-429

Belzile C, Brugel S, Nozais C, Gratton Y, Demers S (2008) Variations of the abundance and nucleic acid content of heterotrophic bacteria in Beaufort Shelf waters during winter and spring. J Mar Syst 74:946-956

Boetius A, Albrecht S, Bakker K, Bienhold C and others (2013) Export of algal biomass from the melting Arctic sea ice. Science 339:1430-1432

Bouillon RC, Lee PA, de Mora SJ, Levasseur M, Lovejoy C (2002) Vernal distribution of dimethylsulphide, dimethylsulphoniopropionate, and dimethylsulphoxide in the North Water in 1998. Deep-Sea Res II 49:5171-5189

Bouvier T, del Giorgio PA, Gasol JM (2007) A comparative study of the cytometric characteristics of high and low-nucleic-acid bacterioplankton cells from different aquatic ecosystems. Environ Microbiol 9:2050-2066

Browse J, Carslaw KS, Arnold SR, Pringle K, Boucher O (2012) The scavenging processes controlling the seasonal cycle in Arctic sulphate and black carbon aerosol. Atmos Chem Phys 12:6775-6798

> Burdige DJ, Homstead J (1994) Fluxes of dissolved organic carbon from Chesapeake Bay sediments. Geochim Cosmochim Acta 58:3407-3424

Chang RYW, Sjostedt SJ, Pierce JR, Papakyriakou TN and others (2011) Relating atmospheric and oceanic DMS levels to particle nucleation events in the Canadian Arctic. J Geophys Res 116(D17):D00S03, doi:10.1029/ 2011JD015926

> Cottrell MT, Kirchman DL (2000) Natural assemblages of marine proteobacteria and members of the CytophagaFlavobacter cluster consuming low- and high-molecularweight dissolved organic matter. Appl Environ Microbiol 66:1692-1697

Cox GFN, Weeks WF (1983) Equations for determining the gas and brine volumes in sea-ice samples. J Glaciol 29: 306-316

del Valle DA, Kiene RP, Karl DM (2012) Effect of visible light on dimethylsulfoniopropionate assimilation and conversion to dimethylsulfide in the North Pacific Subtropical Gyre. Aquat Microb Ecol 66:47-62

> Gabric JA, Qu B, Matrai P, Hirst AC (2005) The simulated response of dimethylsulfide production in the Arctic Ocean to global warming. Tellus Ser B 57:391-403

Galí M, Simó R (2010) Occurrence and cycling of dimethylated sulfur compounds in the Arctic during summer receding of the ice edge. Mar Chem 122:105-117

Galí M, Saló V, Almeda R, Calbet A, Simó R (2011) Stimulation of gross dimethylsulfide (DMS) production by solar radiation. Geophys Res Lett 38:L15612, doi:10.1029/ 2011GL048051

Galindo V, Levasseur M, Mundy CJ, Gosselin M and others (2014) Biological and physical processes influencing sea ice, under-ice algae, and dimethylsulfoniopropionate during spring in the Canadian Arctic Archipelago. J Geophys Res 119:3746-3766

Garneau MÈ, Roy S, Lovejoy C, Gratton Y, Vincent WF (2008) Seasonal dynamics of bacterial biomass and production in a coastal arctic ecosystem: Franklin Bay, west- 
ern Canadian Arctic. J Geophys Res 113(C7):C07S91, doi:10.1029/2007JC004281

- Garrison DL, Buck KR (1986) Organism losses during ice melting: a serious bias in sea ice community studies. Polar Biol 6:237-239

Gilson G (2010) Composition en DMS et composés soufrés associés de la glace de mer annuelle arctique en mer de Beaufort (CFL, Canada) et implication pour les flux de DMS vers l'atmosphère. Master thesis, Université libre de Bruxelles, Belgium

Gosselin M, Levasseur M, Wheeler PA, Horner RA, Booth BC (1997) New measurements of phytoplankton and ice algal production in the Arctic Ocean. Deep-Sea Res II 44: 1623-1644

> Holm-Hansen O, Lorenzen CJ, Holmes RW, Strickland JDH (1965) Fluorometric determination of chlorophyll. J Cons Int Explor Mer 30:3-15

- Howard EC, Sun S, Biers EJ, Moran MA (2008) Abundant and diverse bacteria involved in DMSP degradation in marine surface waters. Environ Microbiol 10:2397-2410

Humphries GR, Huettmann WF, Nevitt GA, Deal C, Atkinson D (2012) Species distribution modeling of storm petrels (Oceanodroma furcata and O. leucorhoa) in the North Pacific and the role of dimethylsulfide. Polar Biol 35:1669-1680

> Jones EP, Swift JH, Anderson LG, Lipizer M and others (2003) Tracing Pacific water in the North Atlantic Ocean. J Geophys Res 108(C4):3116

Kettle AJ, Andreae MO (2000) Flux of dimethylsulfide from the oceans: a comparison of updated data sets and flux models. J Geophys Res 105(D22):26793-26808

Kiene RP, Slezak D (2006) Low dissolved DMSP concentrations in seawater revealed by small-volume gravity filtration and dialysis sampling. Limnol Oceanogr Methods 4: 80-95

> Kiene RP, Linn LJ, Bruton JA (2000) New and important roles for DMSP in marine microbial communities. J Sea Res 43:209-224

Kwint RLJ, Kramer KJM (1995) Dimethylsulphide production by plankton communities. Mar Ecol Prog Ser 121: 227-237

> Lavoie D, Denman KL, Michel C (2005) Modeling ice algal growth and decline in a seasonally ice-covered region of the Arctic (Resolute Passage, Canadian Archipelago). J Geophys Res 110(C11):C11009, doi:10.1029/2005JC002922

> Lebaron P, Servais P, Agogue H, Courties C, Joux F (2001) Does the high nucleic acid content of individual bacterial cells allow us to discriminate between active cells and inactive cells in aquatic systems? Appl Environ Microbiol 67:1775-1782

> Leck C, Larrson U, Bagander LE, Johansson S, Hajdu S (1990) Dimethyl sulfide in the Baltic Sea: annual variability in relation to biological activity. J Geophys Res 95: 3353-3363

> Levasseur M, Gosselin M, Michaud S (1994) A new source of dimethylsulfide (DMS) for the Arctic atmosphere: ice diatoms. Mar Biol 121:381-387

> Levasseur M, Scarratt MG, Michaud S, Merzouk A and others (2006) DMSP and DMS dynamics during a mesoscale iron fertilization experiment in the Northeast Pacific. I. Temporal and vertical distributions. Deep-Sea Res II 53:2353-2369

> Lizotte M, Levasseur M, Kudo I, Suzuki K, Tsuda A, Kiene RP, Scarratt MG (2009) Iron-induced alterations of bacte- rial DMSP metabolism in the western subarctic Pacific during SEEDS-II. Deep-Sea Res II 56:2889-2898

Lizotte M, Levasseur M, Michaud S, Scarratt MG and others (2012) Macroscale patterns of the biological cycling of dimethylsulfoniopropionate (DMSP) and dimethylsulfide (DMS) in the Northwest Atlantic. Biogeochemistry 110: 183-200

Luce M, Levasseur M, Scarratt MG, Michaud S and others (2011) Distribution and microbial metabolism of dimethylsulfoniopropionate and dimethylsulfide during the 2007 Arctic ice minimum. J Geophys Res 116(C9): C00G06, doi:10.1029/2010JC006914

> Malmstrom RR, Kiene RP, Kirchman DL (2004) Identification and enumeration of bacteria assimilating dimethylsulfoniopropionate (DMSP) in the North Atlantic and Gulf of Mexico. Limnol Oceanogr 49:597-606

> Matrai P, Apollonio S (2013) New estimates of microalgae production based upon nitrate reductions under sea ice in Canadian shelf seas and the Canada Basin of the Arctic Ocean. Mar Biol 160:1297-1309

Matrai PA, Keller MD (1993) Dimethylsulfide in a largescale coccolithophore bloom in the Gulf of Maine. Cont Shelf Res 13:831-843

Matrai PA, Vernet M (1997) Dynamics of the vernal bloom in the marginal ice zone of the Barents Sea: dimethylsulfide and dimethylsulfoniopropionate budgets. J Geophys Res 102(C10):22965-22979

> Merzouk A, Levasseur M, Scarratt M, Michaud S, Lizotte M, Rivkin RB, Kiene RP (2008) Bacterial DMSP metabolism during the senescence of the spring diatom bloom in the Northwest Atlantic. Mar Ecol Prog Ser 369:1-11

Michel C, Legendre L, Ingram RG, Gosselin M, Levasseur M (1996) Carbon budget of sea-ice algae in spring: evidence of a significant transfer to zooplankton grazers. J Geophys Res 101(C8):18345-18360

Motard-Côté J, Levasseur M, Scarratt M, Michaud S and others (2012) Distribution and metabolism of dimethylsulfoniopropionate (DMSP) and phylogenetic affiliation of DMSP-assimilating bacteria in northern Baffin Bay/ Lancaster Sound. J Geophys Res 117(C9):C00G11, doi: 10.1029/2011JC007330

Mundy CJ, Barber DG, Michel C (2005) Variability of snow and ice thermal, physical and optical properties pertinent to sea ice algae biomass during spring. J Mar Syst 58:107-120

> Mundy CJ, Gosselin M, Gratton Y, Brown K and others (2014) Role of environmental factors on phytoplankton bloom initiation under landfast sea ice in Resolute Passage, Canada. Mar Ecol Prog Ser 497:39-49

Nicolaus M, Petrich C, Hudson SR, Granskog MA (2013) Variability of light transmission through Arctic land-fast sea ice during spring. The Cryosphere 7:977-986

Parsons TR, Maita Y, Lalli CM (1984) A manual of chemical and biological methods for seawater analysis. Pergamon Press, Oxford

Petrich C, Eicken H (2010) Growth, structure and properties of sea ice. In: Thomas DN, Dieckmann GS (eds) Sea ice, 2nd edn. Wiley-Blackwell, Oxford, p 23-77, doi:10.1002/ 9781444317145.ch2

> Pinhassi J, Simó R, González JM, Vila M and others (2005) Dimethylsulfoniopropionate turnover is linked to the composition and dynamics of the bacterioplankton assemblage during a microcosm phytoplankton bloom. Appl Environ Microbiol 71:7650-7660

Pithan F, Mauritsen T (2014) Arctic amplification dominated 
by temperature feedbacks in contemporary climate models. Nat Geosci 7:181-184

Polashenski C, Perovich D, Courville Z (2012) The mechanisms of sea ice melt pond formation and evolution. J Geophys Res 117(C1):C01001, doi:10.1029/2011JC007231

Pratt KA, Custard KD, Shepson PB, Douglas TA and others (2013) Photochemical production of molecular bromine in Arctic surface snowpacks. Nat Geosci 6:351-356

Pringle DJ, Miner JE, Eicken H, Golden KM (2009) Pore space percolation in sea ice single crystals. J Geophys Res 114:C12017, doi:10.1029/2008JC005145

Prinsenberg SJ, Bennett EB (1987) Mixing and transports in Barrow Strait, the central part of the Northwest Passage. Cont Shelf Res 7:913-935

Qu B, Gabric AJ (2010) Using genetic algorithms to calibrate a dimethylsulfide production model in the Arctic Ocean. Chin J Oceanology Limnol 28:573-582

Reisch CR, Moran MA, Whitman WB (2011) Bacterial catabolism of dimethylsulfoniopropionate (DMSP). Front Microbiol 2:172

Rempillo O, Seguin AM, Norman AL, Scarratt M and others (2011) Dimethylsulfide air-sea fluxes and biogenic sulfur as a source of new aerosols in the Arctic fall. J Geophys Res 116(D17):D00S04, doi:10.1029/2011JD016336

Royer S-J, Levasseur M, Lizotte M, Arychuk M and others (2010) Microbial dimethylsulfoniopropionate (DMSP) dynamics along a natural iron gradient in the northeast subarctic Pacific. Limnol Oceanogr 55:1614-1626

Ruiz-González C, Galí M, Gasol JM, Simó R (2012a) Sunlight effects on the DMSP-sulfur and leucine assimilation activities of polar heterotrophic bacterioplankton. Biogeochemistry 110:57-74

Ruiz-González C, Simó R, Vila-Costa M, Sommaruga R, Gasol JM (2012b) Sunlight modulates the relative importance of heterotrophic bacteria and picophytoplankton in DMSP-sulphur uptake. ISME J 6:650-659

Runge JA, Ingram RG (1991) Under-ice feeding and diel migration by the planktonic copepods Calanus glacialis and Pseudocalanus minutus in relation to the ice algal production cycle in southeastern Hudson Bay, Canada. Mar Biol 108:217-225

Scarratt M, Cantin G, Levasseur M, Michaud S (2000) Particle size-fractionated kinetics of DMS production: Where does DMSP cleavage occur at the microscale? J Sea Res 43:245-252

Simó R (2001) Production of atmospheric sulfur by oceanic plankton: biogeochemical, ecological and evolutionary links. Trends Ecol Evol 16:287-294

Simó R, Pedrós Alió C, Malin G, Grimalt JO (2000) Biological turnover of DMS, DMSP and DMSO in contrasting open sea waters. Mar Ecol Prog Ser 203:1-11

Sokal RR, Rohlf FJ (1995) Biometry: the principles and practice of statistics in biological research, 3rd edn. W. H. Freeman, New York, NY

Stefels J, Steinke M, Turner S, Malin G, Belviso S (2007) Environmental constraints on the production and removal of the climatically active gas dimethylsulphide (DMS) and implications for ecosystem modeling. Biogeochemistry 83:245-275

Stroeve JC, Serreze MC, Holland MM, Kay JE, Malanik J, Barrett AP (2012) The Arctic's rapidly shrinking sea ice cover: a research synthesis. Clim Chang 110:1005-1027

Strom S, Wolfe G, Slajer A, Lambert S, Clough J (2003)

Editorial responsibility: Toshi Nagata,

Kashiwanoha, Japan
Chemical defense in the microplankton. II. inhibition of protist feeding by $\beta$-dimethylsulfoniopropionate (DMSP). Limnol Oceanogr 48:230-237

Tison JL, Brabant F, Dumont I, Stefels J (2010) High resolution dimethylsulfide and dimethylsulfoniopropionate time series profiles in decaying summer first year sea ice at Ice Station Polarstern, western Weddell Sea, Antarctica. J Geophys Res 115(G4):G04044, doi:10.1029/2010JG001427

> Trevena AJ, Jones GB (2006) Dimethylsulphide and dimethylsulphoniopropionate in Antarctic sea ice and their release during sea ice melting. Mar Chem 98:210-222

Uzuka N (2003) A time series observation of DMSP production in the fast ice zone near Barrow. Tohoku Geophys J 36:439-442

Vila-Costa M, Del Valle DA, González JM, Slezak D, Kiene RP, Sánchez O, Simó R (2006) Phylogenetic identification and metabolism of marine dimethylsulfide-consuming bacteria. Environ Microbiol 8:2189-2200

> Vila-Costa M, Simó R, Alonso-Sáez L, Pedrós-Alió C (2008a) Number and phylogenetic affiliation of bacteria assimilating dimethylsulfoniopropionate and leucine in the icecovered coastal Arctic Ocean. J Mar Syst 74:957-963

Vila-Costa M, Kiene RP, Simó R (2008b) Seasonal variability of the dynamics of dimethylated sulfur compounds in a coastal Northwest Mediterranean site. Limnol Oceanogr 53:198-211

> Vila-Costa M, Rinta-Kanto JM, Sun S, Sharma S, Poretsky R, Moran MA (2010) Transcriptomic analysis of a marine bacterial community enriched with dimethylsulfoniopropionate. ISME J 4:1410-1420

> Vila-Costa M, Rinta-Kanto JM, Poretsky RS, Sun S, Kiene RP, Moran MA (2014) Microbial controls on DMSP degradation and DMS formation in the Sargasso Sea. Biogeochemistry 120:295-315

- Whitehead RF, de Mora S, Gosselin M, Monfort P, Mostajir B (2000) Interactions of ultraviolet-B radiation, mixing, and biological activity on photobleaching of natural chromophoric dissolved organic matter: a mesocosm study. Limnol Oceanogr 45:278-291

- Winther JG, Edvardsen K, Gerland S, Hamre B (2004) Surface reflectance of sea ice and under-ice irradiance in Kongsfjorden, Svalbard. Polar Res 23:115-118

Wolfe GV (1996) Accumulation of dissolved DMSP by marine bacteria and its degradation via bacterivory. In: Keine RP, Visscher PT, Keller MD, Kirst GO (eds) Biological and environmental chemistry of DMSP and related sulfonium compounds. Plenum Press, New York, NY, p 277-291

Wolfe GV, Steinke M, Kirst GO (1997) Grazing-activated chemical defense in a unicellular marine alga. Nature 387:894-897

Woodhouse MT, Mann GW, Carslaw KS, Boucher O (2013) Sensitivity of cloud condensation nuclei to regional changes in dimethyl-sulphide emissions. Atmos Chem Phys 13:2723-2733

Zemmelink HJ, Dacey JWH, Houghton L, Hintsa EJ, Liss PS (2008) Dimethylsulfide emissions over the multi-year ice of the western Weddell Sea. Geophys Res Lett 35: L06603, doi:10.1029/2007GL031847

Zhuang G, Yang G, Yu J, Gao Y (2011) Production of DMS and DMSP in different physiological stages and salinity conditions in two marine algae. Chin J Oceanology Limnol 29:369-377

Submitted: June 30, 2014; Accepted: November 30, 2014

Proofs received from author(s): March 2, 2015 